Check for updates

Cite this: Chem. Commun., 2020, 56,6886

Received 29th April 2020,

Accepted 13th May 2020

DOI: $10.1039 / \mathrm{d} 0 \mathrm{cc} 03077 \mathrm{e}$

rsc.li/chemcomm

\section{Additives boosting the performance of tungsten imido-mediated ethylene dimerization systems for industrial application $\uparrow$}

\author{
Antonis M. Messinis, (D) ${ }^{\text {ab }}$ William R. H. Wright, ${ }^{\text {ab }}$ Martin J. Hanton (D) $\ddagger^{* c}$ and \\ Philip W. Dyer (D) *ab
}

\begin{abstract}
While activation of tungsten bis(imido) complexes $\left[\mathrm{WCl}_{2}(\mathrm{NAr})_{2}(\mathrm{dme})\right]$ with $\mathrm{EtAlCl}_{2}$ affords active, and moderately selective ethylene dimerization catalysts, addition of $\mathrm{Et}_{3} \mathrm{~N}$ or $\mathrm{Oct}_{4} \mathrm{NCl}$ leads to a doubling in productivity and activity, along with increased selectivity (e.g., $>93 \%$ $\mathrm{C}_{4},>99 \% 1-\mathrm{C}_{4}$ ). The performance of the resulting tungsten-based catalyst package is competitive with that of Axens' commercialised Ti-based AlphaButol process and exemplifies the wide potential of similar additives in selective oligomerization.
\end{abstract}

Linear alpha olefins (LAOs) are essential components in the manufacture of a host of everyday materials including engine lubricants, plastics, detergents, flavours and fragrances. ${ }^{1}$ As a result, the annual production of LAOs is approximately 5 million metric tons, with a market worth USD 8.26 billion in $2018 .{ }^{1 d}$ In this arena, 1-butene is one of the most important LAOs. Not only is it used as a co-monomer in the production of linear low density polyethylene, LLDPE (with an average annual market increase of $5.3 \%$ ), ${ }^{2}$ but also as the principle starting material for the manufacture of a range of valuable synthetic intermediates. ${ }^{3}$ However, current 1-butene demand exceeds that available through conventional refinery sources necessitating development of alternative supply chains such as catalytic ethylene dimerization. Amongst the homo ${ }^{4}$ and hetero-geneous ${ }^{5}$ catalytic ethylene dimerization systems reported, Axens' AlphaButol process stands out, producing $25 \%$ of the total 1-butene consumed worldwide since the mid-1980s. ${ }^{2}$ AlphaButol's success can be attributed mainly to the use of inexpensive titanium alkoxides, reasonable activity of up to $21 \times 10^{3}\left(\mathrm{~mol} \mathrm{C}_{2} \mathrm{H}_{4}\right)(\mathrm{mol} \mathrm{Ti})^{-1} \mathrm{~h}^{-1}$, good productivity of $\sim 250 \mathrm{~g}$ ethylene converted per hour, low polyethylene make, and excellent selectivity of up to $95 \mathrm{wt} \%$ 1-butene content. $^{6}$ These impressive performance parameters make it

\footnotetext{
${ }^{a}$ Center for Sustainable Chemical Processes, Department of Chemistry, Durham University, South Road, Durham, DH1 3LE, UK. E-mail: p.w.dyer@durham.ac.uk

${ }^{b}$ Department of Chemistry, Durham University, South Road, Durham, DH1 3LE, UK

${ }^{c}$ Sasol UK Ltd, Purdie Building, North Haugh, St Andrews, Fife, KY16 9ST, UK

$\dagger$ Electronic supplementary information (ESI) available. See DOI: 10.1039/ d0cc03077e

\$ Current address: TÜV SÜD Ltd, East Kilbride, Glasgow, G75 0QF, UK.
}

challenging to establish different, economically competitive ethylene dimerization catalysts. Currently, although many of the alternatives are reasonably active, they lack the selectivity (giving both polymer and 2-butene) and/or productivity (low ethylene conversions of only a few grams) necessary for industrial application. ${ }^{7}$

In this context, we recently described the dimerization of ethylene mediated by tungsten bis(imido) complexes activated with $\mathrm{EtAlCl}_{2}$. These systems achieve high activities and productivities, albeit with only moderate selectivities (up to $409 \times$ $10^{3}\left(\mathrm{~mol} \mathrm{C}_{2} \mathrm{H}_{4}\right)(\mathrm{mol} \mathrm{W})^{-1} \mathrm{~h}^{-1}$ and 1-butene selectivity of up to $82 \mathrm{wt} \%)^{8}$ In order to enhance the performance of these tungsten-based systems we sought to exploit the use of so-called "modifiers" (e.g., $\mathrm{THF}^{6 a} \mathrm{Et}_{3} \mathrm{~N},{ }^{9 d} \mathrm{Et}_{4} \mathrm{NCl}^{9 c} \mathrm{Ph}_{3} \mathrm{P},{ }^{9 d}$ and $\mathrm{Ph}_{3} \mathrm{PO}^{9 d}$ ). These have previously been reported to give enhancements in catalytic ethylene oligomerization performance of titanium- ${ }^{6 a, 9}$ nickel-,${ }^{10}$ cobalt- $-{ }^{11}$ and zirconium-based systems, ${ }^{12}$ but have surprisingly received very little subsequent attention in the literature. Therefore, we now describe our findings on the effects of the modifiers Oct $\mathrm{NCl}\left(\mathrm{Oct}=\right.$ octyl) and $\mathrm{Et}_{3} \mathrm{~N}$ on catalysis initiated by tungsten bis(imido) pro-catalysts. We highlight not only the extremely beneficial effects of the modifiers, but also demonstrate the development of a tungsten-based dimerization system that rivals the performance of the commercialised AlphaButol process.

Pro-catalysts 1-3 (Chart 1) were chosen as a starting point for this investigation of the effect of modifiers since their dimerization behaviour has been explored in detail previously and showed promising performance. ${ }^{8}$ Thus, a baseline catalytic performance of complexes 1-3 activated with $15 \mathrm{EtAlCl}_{2}$ was first established as summarised in Table 1 (full details are presented in the ESI $\dagger$ ). Note, where catalytic tests resulted in filling of the reactor vessel to capacity, the productivities (TONs) reported in Table 1 are underestimated since catalysis had to be stopped. As established previously, a limiting concentration of tungsten $\geq 0.2 \mathrm{mM}$ is required for productive catalysis. ${ }^{8}$ Subsequently, we explored the effect of the potential modifiers $\mathrm{Et}_{3} \mathrm{~N}$ and $\mathrm{Oct}_{4} \mathrm{NCl}$ (the latter preferred over $\mathrm{Et}_{4} \mathrm{NCl}$ due to its greater solubility) upon the catalytic performance of 


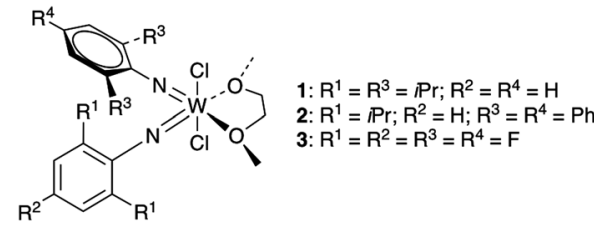

Chart 1 Tungsten bis(imido) pro-catalysts 1-3.

Table 1 Catalytic performance of complexes 1-3 at 45 barg ethylene pressure and $70{ }^{\circ} \mathrm{C}$ under varying conditions ${ }^{a}$

Pro-cat. [W], g $t, \quad$ TON $^{b} \quad$ Activity $^{c}$ Prod. $\quad \mathrm{C}_{4}, \mathrm{wt} \%$ Entry $(\mu \mathrm{mol}) \mathrm{dm}^{-3} \min \left(\times 10^{-3}\right)\left(\times 10^{-3}\right)$ mass, $\mathrm{g}\left(\% 1-\mathrm{C}_{4} \text { in } \mathrm{C}_{4}\right)^{d}$ \begin{tabular}{llllllll}
\hline $1^{e}$ & $1(20)$ & 270 & 45 & 134 & 179 & 75 & $73(98)$
\end{tabular}

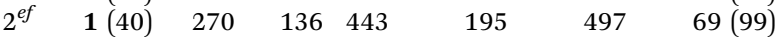

$\begin{array}{llllllll}3^{e} & 2(20) & 270 & 29 & 143 & 293 & 80 & 74(98)\end{array}$

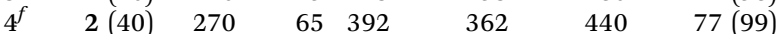

$\begin{array}{llllllll}5^{e} & 3(20) & 270 & 21 & 142 & 409 & 80 & 82(98)\end{array}$

$\begin{array}{llllllll}6^{f} & 3(40) & 270 & 105 & 362 & 208 & 406 & 84(98)\end{array}$

${ }^{a}$ Conditions: 15 eq. $\mathrm{EtAlCl}_{2}$; $\mathrm{PhCl}(74 \mathrm{~mL}) ; 70{ }^{\circ} \mathrm{C}$; ethylene pressure 45 barg; stirrer speed $1000 \mathrm{rpm}$; nonane standard (1.000 mL); $0.25 \mathrm{~L}$ reactor; no polyethylene detected. Unless stated otherwise, catalytic runs were performed until consumption of $\mathrm{C}_{2} \mathrm{H}_{4}$ dropped below $0.2 \mathrm{~g} \mathrm{~min}{ }^{-1}$ or until the reactor was filled. ${ }^{b}$ TON (productivity) reported in $\left(\mathrm{mol} \mathrm{C}_{2} \mathrm{H}_{4}\right)(\mathrm{mol} \mathrm{W})^{-1}$. ${ }^{c}$ Activity (TOF) reported in $\left(\mathrm{mol} \mathrm{C}_{2} \mathrm{H}_{4}\right)(\mathrm{mol} \mathrm{W})^{-1} \mathrm{~h}^{-1}$. ${ }^{d}$ Selectivity to butenes and selectivity of 1-butene in the butenes fraction. ${ }^{e}$ Reaction mixture filled reactor so reported activity and selectivity are underestimated. ${ }^{f}$ Performed in a $1.2 \mathrm{~L}$ reactor with $148 \mathrm{~mL} \mathrm{PhCl}$ and $2.000 \mathrm{~mL}$ nonane standard.

1-3/EtAlCl 2 . The use of ammonium chloride salts was considered a promising starting point since it has been demonstrated previously that increasing the chloride content in the activator (e.g., replacing $\mathrm{Et}_{3} \mathrm{Al}$ by $\mathrm{EtAlCl}_{2}$ ) is beneficial to catalysis with this type of tungsten imido system as well as having been shown to modulate the selectivity of related titanium and tantalum polymerisation catalysts. ${ }^{9 b, 13}$

Solutions of each of the pro-catalysts 1-3 were treated with either $\mathrm{Et}_{3} \mathrm{~N}$ or $\mathrm{Oct}_{4} \mathrm{NCl}$ prior to activation with $\mathrm{EtAlCl}_{2}$, and the resulting systems tested for their ethylene dimerization performance. The data summarized in Fig. 1 show that addition of $\mathrm{Et}_{3} \mathrm{~N}$ and, especially $\mathrm{Oct}_{4} \mathrm{NCl}$, leads to significant improvements in catalytic activity and selectivity compared with those achieved in the absence of modifiers. Addition of 4 eq. of $\mathrm{Et}_{3} \mathrm{~N}$ before activation of 1 with 15 equivalents $\mathrm{EtAlCl}_{2}$ leads to a doubling in activity (Table 2, entry 2), while use of $\mathrm{Oct}_{4} \mathrm{NCl}$ gave rise to a roughly three-fold increase. Furthermore, the addition of $\mathrm{Et}_{3} \mathrm{~N}$ and $\mathrm{Oct}_{4} \mathrm{NCl}$ also leads to improvements in both the selectivity towards the dimer fraction (from 73 to $87 \%$ for 6 eq. of modifier added) and in the selectivity to 1-butene within the dimers fraction (98 to 99\%). This level of performance brings the selectivity towards butenes for the bis(imido) tungsten pro-catalysts to within $8 \mathrm{wt} \%$ of that reported for AlphaButol, while matching performance in terms of selectivity towards 1-butene within the $\mathrm{C}_{4}$ fraction. $^{6 a}$

The increase in the percentage of 1-butene within the $\mathrm{C}_{4}$ fraction is especially significant since 1-butene of low purity is not suitable for polyethylene manufacturing applications (its principle market), requiring costly super-fractionation prior

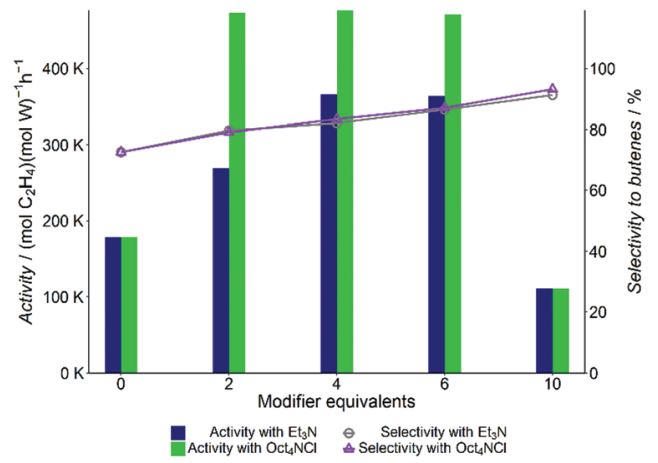

Fig. 1 Comparison of ethylene dimerization activity and selectivity to butenes (wt\%) of $20 \mu \mathrm{mol}$ of 1 activated with $\mathrm{EtAlCl}_{2}$ (15 eq.) at various amounts of $\mathrm{Et}_{3} \mathrm{~N}$ and $\mathrm{Oct}_{4} \mathrm{NCl}$.

Table 2 Effect of $\mathrm{Et}_{3} \mathrm{~N}$ and $\mathrm{Oct}_{4} \mathrm{NCl}$ on the catalytic performance of pro-catalysts 1-3 in combination with $\mathrm{EtAlCl}_{2}$ at 45 barg ethylene pressure and $70{ }^{\circ} \mathrm{C}^{a}$

\begin{tabular}{|c|c|c|c|c|c|c|c|}
\hline Entry & $\begin{array}{l}\text { Pro- } \\
\text { cat. }\end{array}$ & $\begin{array}{l}\text { Modifier } \\
\text { (eq.) }\end{array}$ & $\begin{array}{l}t, \\
\min \end{array}$ & $\begin{array}{l}\operatorname{TON}^{b} \\
\left(\times 10^{-3}\right)\end{array}$ & $\begin{array}{l}\text { Activity } \\
\left(\times 10^{-3}\right)\end{array}$ & $\begin{array}{l}\text { Prod. } \\
\text { mass, } g\end{array}$ & $\begin{array}{l}\mathrm{C}_{4}, \mathrm{wt} \% \\
\left(\% 1-\mathrm{C}_{4} \text { in } \mathrm{C}_{4}\right)^{d}\end{array}$ \\
\hline 1 & 1 & $\mathrm{Et}_{3} \mathrm{~N}(2)$ & 32 & 144 & 269 & 81 & $80(99)$ \\
\hline 2 & 1 & $\mathrm{Et}_{3} \mathrm{~N}(4)$ & 23 & 144 & 366 & 81 & $81(99)$ \\
\hline 3 & 1 & $\mathrm{Et}_{3} \mathrm{~N}(6)$ & 24 & 144 & 364 & 81 & 87 (99) \\
\hline 4 & 1 & $\mathrm{Et}_{3} \mathrm{~N}(10)$ & 55 & 102 & 111 & 57 & 91 (99) \\
\hline 5 & 1 & $\mathrm{Oct}_{4} \mathrm{NCl}(2)$ & 18 & 143 & 473 & 81 & $79(99)$ \\
\hline 6 & 1 & $\mathrm{Oct}_{4} \mathrm{NCl}(4)$ & 18 & 142 & 477 & 80 & $83(99)$ \\
\hline 7 & 1 & $\mathrm{Oct}_{4} \mathrm{NCl}(6)$ & 18 & 140 & 471 & 79 & $87(99)$ \\
\hline 8 & 1 & $\mathrm{Oct}_{4} \mathrm{NCl}(10)$ & 19 & 36 & 111 & 20 & $93(99)$ \\
\hline 9 & 2 & $\mathrm{Et}_{3} \mathrm{~N}(4)$ & 15 & 142 & 574 & 80 & $80(99)$ \\
\hline 10 & 2 & $\mathrm{Oct}_{4} \mathrm{NCl}(2)$ & 15 & 141 & 574 & 79 & 79 (99) \\
\hline 11 & 3 & $\mathrm{Et}_{3} \mathrm{~N}(4)$ & 46 & 15 & 20 & 8 & $93(97)$ \\
\hline 12 & 3 & $\mathrm{Oct}_{4} \mathrm{NCl}(2)$ & 34 & 142 & 248 & 79 & $86(98)$ \\
\hline $13^{e f}$ & 1 & $\mathrm{Oct}_{4} \mathrm{NCl}(2)$ & 38 & 368 & 584 & 413 & $84(99)$ \\
\hline $14^{e}$ & 1 & $\mathrm{Oct}_{4} \mathrm{NCl}(2)$ & 62 & 708 & 690 & 397 & $84(99)$ \\
\hline $15^{e}$ & 2 & $\mathrm{Oct}_{4} \mathrm{NCl}(2)$ & 89 & 675 & 458 & 379 & $82(99)$ \\
\hline
\end{tabular}

${ }^{a}$ Conditions: $20 \mu \mathrm{mol} \mathrm{W}$; 15 eq. $\mathrm{EtAlCl}_{2}$; $\mathrm{PhCl}(74 \mathrm{~mL}) ; 70{ }^{\circ} \mathrm{C}$; ethylene pressure 45 barg; stirrer speed $1000 \mathrm{rpm}$; nonane standard $(1.000 \mathrm{~mL})$; no polyethylene was detected. ${ }^{b}$ TON (productivity) is reported in $\left(\mathrm{mol} \mathrm{C}_{2} \mathrm{H}_{4}\right)(\mathrm{mol} \mathrm{W})^{-1} \cdot{ }^{c}$ TOF (activity) is reported in $\left(\mathrm{mol} \mathrm{C}_{2} \mathrm{H}_{4}\right)$ (mol W) ${ }^{-1} \mathrm{~h}^{-1}$. ${ }^{d}$ Selectivity to butenes expressed in wt\% and \%selectivity of 1-butene in the butenes fraction. ${ }^{e}$ Performed in a $1.2 \mathrm{~L}$ reactor with $148 \mathrm{~mL} \mathrm{PhCl}$ and $2.000 \mathrm{~mL}$ nonane standard. ${ }^{f} 40 \mu \mathrm{mol} \mathrm{W}$ used.

to use. ${ }^{7}$ In addition, for pro-catalyst 1 the selectivity towards butenes was found to increase almost linearly with the amount of modifier used (Fig. 1), reaching values of 93 wt\% when 10 eq. of Oct $_{4} \mathrm{NCl}$ are employed. This degree of selectivity is, within experimental error, analogous to that reported for AlphaButol. $^{6,14}$ However, this enhanced selectivity achieved with $1 / \mathrm{Oct}_{4} \mathrm{NCl} / \mathrm{EtAlCl}_{2}$ came at a cost to this system's activity and productivity (Table 2, entries 1-8).

Similar to the change in catalytic performance observed with pro-catalyst 1 in combination with $4 \mathrm{Et}_{3} \mathrm{~N}$ or $2 \mathrm{Oct}_{4} \mathrm{NCl}$, procatalyst 2 also demonstrated increased activity in the presence of each of the modifiers, reaching a value of over $500 \times 10^{3}$ $\left(\mathrm{mol} \mathrm{C}_{2} \mathrm{H}_{4}\right)(\mathrm{mol} \quad \mathrm{W})^{-1} \mathrm{~h}^{-1}$ whilst maintaining selectivity towards $\mathrm{C}_{4}$ of $\sim 80 \mathrm{wt} \%$ (Table 2 , entries 9 and 10). In marked contrast, pro-catalyst 3 was poisoned by both $\mathrm{Et}_{3} \mathrm{~N}$ and $\mathrm{Oct}_{4} \mathrm{NCl}$, resulting in a dramatic decrease in activity from $409 \times 10^{3}$ to 
$20 \times 10^{3}$ and $248 \times 10^{3}\left(\mathrm{~mol} \mathrm{C}_{2} \mathrm{H}_{4}\right)(\mathrm{mol} \mathrm{W})^{-1} \mathrm{~h}^{-1}$, respectively (Table 2, entries 11 and 12). Additionally, the selectivity towards 1-butene in the $\mathrm{C}_{4}$ fraction using pro-catalyst 3 combined with $\mathrm{Et}_{3} \mathrm{~N}$ or $\mathrm{Oct}_{4} \mathrm{NCl}$ was not as good as that obtained using pro-catalysts 1 and 2 (97\% and 98\% vs. >99\%).

Since catalysis employing complexes 1 and 2 in combination with $\mathrm{EtAlCl}_{2}$ and $\mathrm{Oct}_{4} \mathrm{NCl}$ filled a $0.25 \mathrm{~L}$ reactor to capacity, further testing was carried out in a $1.2 \mathrm{~L}$ vessel. Catalysis mediated by pro-catalyst $1(40 \mu \mathrm{mol})$ in combination with EtAlCl$_{2}$ (15 eq.) and 2 eq. of Oct $_{4} \mathrm{NCl}$ led to formation of $413 \mathrm{~g}$ of product, filling the $1.2 \mathrm{~L}$ reactor to capacity. This corresponds to an activity of $584 \times 10^{3}\left(\mathrm{~mol} \mathrm{C}_{2} \mathrm{H}_{4}\right)(\mathrm{mol} \mathrm{W})^{-1} \mathrm{~h}^{-1}$ (Table 2, entry 13), surpassing the activity of the same system achieved in the $0.25 \mathrm{~L}$ reactor (Table 2, entry 5) by $100 \times$ $10^{3}\left(\mathrm{~mol} \mathrm{C}_{2} \mathrm{H}_{4}\right)(\mathrm{mol} \mathrm{W})^{-1} \mathrm{~h}^{-1}$. This increase in activity observed when the experiment from entry 5 of Table 2 was repeated in the $1.2 \mathrm{~L}$ reactor $\$$ suggests that when the latter test was stopped (since the reactor had been filled; see ESI $\dagger$ ) the reaction was in the nascent stages of catalysis and that even higher activities and productivities should be possible if catalysis was allowed to reach completion. This behaviour became more evident on comparing the shape of the ethylene conversion profiles (Fig. 2) as a function of time for high-performing reactions, where the reactor was filled (Table 2, entries 5 and 14), and poorlyperforming reactions where catalysis stopped as a result of catalyst deactivation (e.g., Table 2, entry 4 ) resulting in a plateau in the reaction profile (Fig. 2, dotted line). A similar trend was observed for the reaction selectivity: the longer catalysis was run the more selective the system became, something demonstrated by the increase in selectivity towards butenes from 79 to $84 \mathrm{wt} \%$ when the reaction described in entry 5 of Table 2 was performed in the larger $1.2 \mathrm{~L}$ reactor (Table 2, entry 13 ). This increased selectivity when the reaction was run at higher productivities is characteristic of the tungsten imido systems and results from the majority of by-products being formed during the activation phase of the catalytic system. ${ }^{8}$

When the test employing $40 \mu \mathrm{mol}$ of pro-catalyst 1 (Table 2, entry 13) was repeated with half the amount of 1 (Table 2, entry 14), an extremely high-performing system was achieved, with a

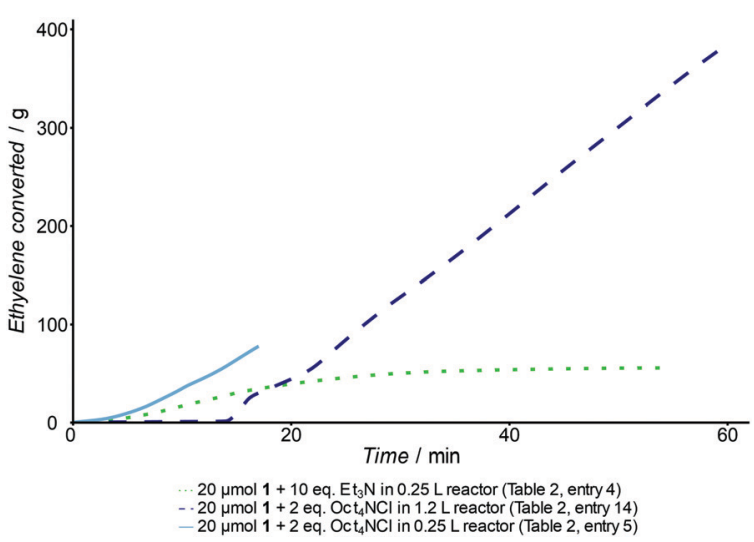

Fig. 2 Amount of ethylene converted to products over time for pro-catalyst 1 with 2 eq. $\mathrm{Oct}_{4} \mathrm{NCl}$ or 10 eq. $\mathrm{Et}_{3} \mathrm{~N}$ modifier in a $250 \mathrm{~mL}$ and $1.2 \mathrm{~L}$ reactor. Catalysis with 1 and 2 eq. Oct ${ }_{4} \mathrm{NCl}$ was far from completion at the point the reactor became filled demonstrating the industrial potential of these systems. productivity of $708 \times 10^{3}\left(\mathrm{~mol} \mathrm{C}_{2} \mathrm{H}_{4}\right)\left(\mathrm{mol} \mathrm{W}^{-1}\right.$, an activity of $690 \times$ $10^{3}\left(\mathrm{~mol} \mathrm{C}_{2} \mathrm{H}_{4}\right)(\mathrm{mol} \mathrm{W})^{-1} \mathrm{~h}^{-1}$, selectivity to butenes and to to 1-butene within the $\mathrm{C}_{4}$ fraction off $84 \mathrm{wt} \%$ and $99 \%$, respectively. Here, again, the nature of the imido substituents is intimately linked to controlling catalytic performance; repeating the same test with pro-catalyst $2(20 \mu \mathrm{mol})$ rather than 1 gave poorer results (Table 2, entry 14).

Notably, the activity and productivity achieved employing $20 \mu \mathrm{mol}$ of pro-catalyst 1 (Table 2 , entry 14 ) are both at least 30 times higher than those reported for the commercial AlphaButol titanium alkoxide-based systems. ${ }^{6,7,9 a, c, d, 14,15}$ Additionally, both the selectivity towards 1-butene within the $\mathrm{C}_{4}$ fraction and the extent of polymer formation is very similar for both the tungsten and titanium systems, although Alphabutol shows slightly higher selectivity $(\sim 8 \mathrm{wt} \%)$ to $\mathrm{C}_{4}$.

Currently, the mode of action by which $\mathrm{Et}_{3} \mathrm{~N}$ and Oct $_{4} \mathrm{NCl}$ improve the catalytic performance of the tungsten bis(imido) pro-catalysts 1 and 2 activated by $\mathrm{EtAlCl}_{2}$ remains elusive. Indeed, the activation pathway of transition metal polymerization and oligomerization pro-catalysts continues to be a topic of debate. ${ }^{16,17}$ Neither complex 1 nor 2 reacts with either $\mathrm{Et}_{3} \mathrm{~N}$ or $\mathrm{Oct}_{4} \mathrm{NCl}$. However, in contrast, the reaction of complex 1 with 6 eq. of $\mathrm{EtAlCl}_{2}$ leads to the formation of multiple unassignable products, together with ethane $\left(\mathrm{W}: \mathrm{C}_{2} \mathrm{H}_{6}=1: 1\right)$. This is consistent with Al-to-W transmetalation to afford a tungsten diethyl species, which undergoes $\beta$-hydride elimination and reductive elimination. While no further reaction takes place on subsequent addition of ethylene at 1 barg, performing this reaction in the presence of ethylene ( $>10 \mathrm{barg}$ ) results in ethylene dimerization. ${ }^{8}$

Previously we have shown that 1 reacts with 6 eq. $\mathrm{Me}_{3} \mathrm{Al}$ to yield $\left[\mathrm{WMe}_{2}\left(\mathrm{~N}\{\mathrm{Dipp}\} \mathrm{AlMe}_{2}\{\mu-\mathrm{Cl}\}\right)(\mathrm{NDipp})\right](\mathbf{4})$, which is inert towards ethylene. ${ }^{18}$ However, reaction of 4 with THF or $\mathrm{NEt}_{3}$, displaces the bound $\mathrm{Me}_{2} \mathrm{AlCl}$ forming a labile complex $\left[\mathrm{WMe}_{2}(\mathrm{NDipp})_{2}(\mathrm{~L})\right]\left(\mathrm{L}=\mathrm{THF}, \mathrm{NEt}_{3}\right)$, which is active for catalytic ethylene dimerization. Consequently, it is proposed tentatively that these modifiers enhance catalytic activity by scavenging the residual aluminium salt from the tungsten during or after alkylation has occurred. For instance, triethylamine can react with $\mathrm{R}_{x} \mathrm{AlCl}_{(3-x)}$ to form adducts of the type $\mathrm{Et}_{3} \mathrm{~N} \cdot \mathrm{AlCl}_{(3-x)} \mathrm{R}_{x},{ }^{19}$ while reaction with Oct $_{4} \mathrm{NCl}$ affords aluminate salts such as $\left[\mathrm{Oct}_{4} \mathrm{~N}\right]\left[\mathrm{Al}_{2} \mathrm{Et}_{2} \mathrm{Cl}_{5}\right]$ or $\left[\mathrm{Oct}_{4} \mathrm{~N}\right]\left[\mathrm{AlCl}_{4}\right]^{20}$

Thus, the presence of either $\mathrm{Et}_{3} \mathrm{~N}$ or $\mathrm{Oct}_{4} \mathrm{NCl}$ gives enhanced catalytic performance as a result of efficient formation of the necessary coordinatively unsaturated tungsten species. ${ }^{19}$ Higher concentrations of the modifiers (e.g., 10 eq. relative to tungsten, see Fig. 1) will eventually lead to their coordination at tungsten, thus blocking olefin binding hence reducing the system's catalytic performance. These conclusions are also consistent with the poor ethylene dimerization performance of complex 3: the electron withdrawing nature of the trifluorophenyl group results in strong coordination of the Lewis basic additive to the tungsten centre stabilizing it to an extent that hampers increased reactivity.

In summary, complexes 1-3 in combination with 15 eq. of $\mathrm{EtAlCl}_{2}$ are active and moderately selective catalysts for the 
dimerization of ethylene. However, the addition of $\mathrm{Et}_{3} \mathrm{~N}$ or $\mathrm{Oct}_{4} \mathrm{NCl}$ as modifiers significantly boosts activity, productivity, and selectivity of both pro-catalysts 1 and 2 . The resulting catalytic performance of the pro-catalyst 1,2/modifier package is entirely comparable to that of the principle ethylene dimerization system used commercially for the production of 1-butene, AlphaButol. ${ }^{6}$ Importantly, this study indicates that the full potential of the tungsten imido ethylene dimerization system has yet to be fully realized in terms of activity, productivity, and selectivity. Additional advances are expected in the future following an on-going exploration of the mode of action of these modifiers with bis(imido) tungsten pro-catalysts. We have demonstrated here that modifiers act on the aluminium activators rather than the transition metal pro-catalyst component and so, consequently, we propose that this is something that is not specific to just these tungsten bis(imido) systems, but rather should be very widely applicable to the many different types of previously explored selective oligomerization catalysts.

The authors thank Sasol Group Technology, the EPSRC, and Durham University for funding and permission to publish this work. Dr David Smith of Sasol is thanked for fruitful discussions.

\section{Conflicts of interest}

There are no conflicts to declare.

\section{Notes and references}

$\S$ This effect is also observed when the catalytic performance of procatalysts 1 and 2 was tested without modifiers, Table 1, entries 3 vs. 4 .

1 (a) J. C. Mol, J. Mol. Catal. A: Chem., 2004, 213, 39; (b) W. Kaminsky and M. Arndt-Rosenau, Applied Homogeneous Catalysis with Organometallic Compounds, Wiley-VCH Verlag GmbH, 2008, p. 213; (c) C. Bergemann, R. Cropp and G. Luft, J. Mol. Catal. A: Chem., 1996, 105, 87; (d) M. Morgan, Chem. Bull., 2016, 2 , 3.

2 G. P. Belov and P. E. Matkovsky, Pet. Chem., 2010, 50, 283.

3 F. M. Geilen, G. Stochniol, S. Peitz and E. Schulte-Koerne, Ullmann's Encyclopedia of Industrial Chemistry, 2014.

4 (a) S. J. Song, Y. Li, C. Redshaw, F. S. Wang and W. H. Sun, J. Organomet. Chem., 2011, 696, 3772; (b) M. Shiotsuki, P. S. White, M. Brookhart and J. L. Templeton, J. Am. Chem. Soc., 2007, 129, 4058; (c) W. R. H. Wright, A. S. Batsanov, A. M. Messinis, J. A. K. Howard, R. P. Tooze, M. J. Hanton and P. W. Dyer, Dalton Trans., 2012, 41, 5502; (d) S. Zhang and K. Nomura, J. Am. Chem. Soc., 2010, 132, 4960; (e) F. Speiser, P. Braunstein and W. Saussine, Acc. Chem. Res., 2005, 38, 784; $(f)$ A. M. Al-Jarallah, J. A. Anabtawi, M. A. B. Siddiqui, A. M. Aitani and A. W. Al-Sa'doun, Catal. Today, 1992, 14, 1.
5 (a) H. Zhang, X. Li, Y. Zhang, S. Lin, G. Li, L. Chen, Y. Fang, H. Xin and X. Li, Energy Environ. Focus, 2014, 3, 246; (b) A. Finiels, F. Fajula and V. Hulea, Cat. Sci. Technol., 2014, 4, 2412; (c) M. J. Lamb, D. C. Apperley, M. J. Watson and P. W. Dyer, Top. Catal., 2018, 61, 213; (d) Z. Xu, J. P. Chada, L. Xu, D. Zhao, D. C. Rosenfeld, J. L. Rogers, I. Hermans, M. Mavrikakis and G. W. Huber, ACS Catal., 2018, 8, 2488.

6 (a) L. Magna and H. Olivier-Bourbigou, IFP, US/2016/002124 A1, 2016; (b) N. Le Quan, D. Cruypelinck, D. Commereur, Y. Chauvin and G. Leger, IFP Energies Nouvelles, EP0135441 B1, 1985; (c) L. Magna and H. Olivier-Bourbigou, IFP, US9499455 B2, 2016.

7 F. A. Al-Sherehy, in Stud. Surf. Sci. Catal., ed. M. Absi-Halabi, J. Beshara and A. Stanislaus, Elsevier, 1996, vol. 100, p. 515.

8 A. M. Messinis, A. S. Batsanov, W. R. H. Wright, J. A. K. Howard, M. J. Hanton and P. W. Dyer, ACS Catal., 2018, 8, 11249.

9 (a) P. Bigdeli, M. Abdouss and S. Abedi, Chem. Eng. Commun., 2018, 205, 102; (b) S. Murtuza, S. B. Harkins, G. S. Long and A. Sen, J. Am. Chem. Soc., 2000, 122, 1867; (c) D. Commereuc, F. Hugues and Y. Glaize, IFP, SABIC, US5877376, 1999; (d) A. W. Al-Sa'doun, Appl. Catal., A, 1993, 105, 1.

10 (a) F. K. Shmidt, V. S. Tkach and A. V. Kalabina, Pet. Chem., 1972, 12, 18; (b) J. Pietsch, P. Braunstein and Y. Chauvin, New J. Chem., 1998, 22, 467; (c) W.-H. Sun, W. Zhang, T. Gao, X. Tang, L. Chen, Y. Li and X. Jin, J. Organomet. Chem., 2004, 689, 917; (d) S. Song, T. Xiao, T. Liang, F. Wang, C. Redshaw and W.-H. Sun, Catal. Sci. Technol., 2011, 1, 69.

11 (a) H. Liu, F. Wang, L. Liu, B. Dong, H.-X. Zhang, C.-X. Bai, Y.-M. Hu and X.-Q. Zhang, Inorg. Chim. Acta, 2014, 421, 284; (b) R. Cariou, J. J. Chirinos, V. C. Gibson, G. Jacobsen, A. K. Tomov, G. J. P. Britovsek and A. J. P. White, Dalton Trans., 2010, 39, 9039.

12 Y. Shiraki, Y. Nakamoto and Y. Souma, J. Mol. Catal. A: Chem., 2002, 187, 283.

13 M. Hanton, L. Daubney, T. Lebl, S. Polas, D. M. Smith and A. Willemse, Dalton Trans., 2010, 39, 7025.

14 (a) J. B. Cazaux, P. Braunstein, L. Magna, L. Saussine and H. OlivierBourbigou, Eur. J. Inorg. Chem., 2009, 2942; (b) F. Grasset, J. B. Cazaux, L. Magna, P. Braunstein and H. Oliver-Bourbigou, Dalton Trans., 2012, 41, 10396; (c) F. Grasset and L. Magna, IFP, US8624042 B2, 2014.

15 (a) I. Ono, S. Yamada, H. Abe, K. Tago and N. Kunihiro, US3686350, 1972; (b) V. I. Zhukov, N. P. Shestak, G. P. Belov, M. N. Dyadjunova, L. A. Shilov, I. D. Shevlyakov, F. S. Dyachkovsky, A. G. Liakumovich and P. A. Vernov, US4101600, 1978.

16 (a) F. Zaccaria, L. Sian, C. Zuccaccia and A. Macchioni, Adv. Organomet. Chem., Elsevier, 1st edn, 2020, vol. 73, pp. 1-78; (b) C. Götz, A. Rau and G. Luft, J. Mol. Catal. A: Chem., 2002, 184, 95; (c) M. Bochmann and M. J. Sarsfield, Organometallics, 1998, 17, 5908.

17 (a) W. R. H. Wright, A. S. Batsanov, J. A. K. Howard, R. P. Tooze, M. J. Hanton and P. W. Dyer, Dalton Trans., 2010, 39, 7038; (b) S. Tobisch, Procedia Comput. Sci., 2011, 4, 1203.

18 W. R. H. Wright, A. S. Batsanov, J. A. K. Howard, R. P. Tooze, M. J. Hanton and P. W. Dyer, Dalton Trans., 2010, 39, 7038.

19 (a) E. W. Abel, F. G. A. Stone and P. G. Harrison, in Organomet. Chem., ed. E. W. Abel, F. G. A. Stone, 1986, vol. 14, ch. 5, RSC, Cambridge, pp. 59-82; (b) F. M. Peters, A. J. Bilbo and B. Bartocha, Can. J. Chem., 1963, 41, 1051.

20 S. A. Sangokoya and G. H. Robinson, J. Inclusion Phenom., 1988, 6, 263. 